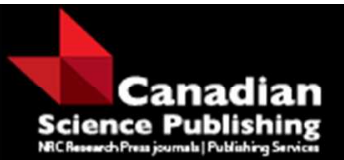

Canadian Journal of Forest Research

Revue canadienne de recherche forestière

\title{
Growth release of stunted black spruce (Picea mariana) in Kalmia heath: The role of ectomycorrhizal fungi and near- ground microclimate
}

\begin{tabular}{|r|l|}
\hline Journal: & Canadian Journal of Forest Research \\
\hline Manuscript ID & cjfr-2015-0267.R3 \\
\hline Manuscript Type: & Article \\
\hline Date Submitted by the Author: & 22-Feb-2016 \\
\hline Complete List of Authors: & $\begin{array}{l}\text { St. Martin, Philippe; Lakehead University, Biology } \\
\text { Mallik, Azim ; Lakehead University, Department of Biology }\end{array}$ \\
\hline Keyword: & $\begin{array}{l}\text { organic matter depth, fire severity, fungal DNA, conifer regeneration } \\
\text { failure, Kalmia dominance }\end{array}$ \\
\hline \multicolumn{2}{|l}{} \\
\hline
\end{tabular}

SCHOLARONE

Manuscripts 
Growth release of stunted black spruce (Picea mariana) in Kalmia heath: The role of ectomycorrhizal fungi and near-ground microclimate

Philippe St. Martin and Azim U. Mallik ${ }^{1}$

Department of Biology, Lakehead University, Thunder Bay, Ontario, Canada P7B 5E1

1Corresponding Author: Email: amallik@lakeheadu.ca, Phone: (807) 343-8927 


\section{Abstract}

2 Naturally regenerating and planted black spruce (Picea mariana [Mill.] BSP) in post-fire

3 landscapes in eastern Canada often exhibit stunted growth in the presence of ericaceous shrubs

4 such as Kalmia angustifolia (L.). After a period of stunted growth, some seedlings experience a

5 growth release exhibiting growth rates closer to normally growing seedlings. We hypothesized

6 that an increase in colonization of root tips by ectomycorrhizal (ECM) fungi is responsible for

7 this release and that the percentage of root tips colonized by ECM fungi would be higher on

8 seedlings which had a released or normally growing neighbour within close proximity. We

9 quantified ECM fungi diversity and abundance from 255 soil cores from stunted, released, and

10 normally growing black spruce seedlings sampled in two Kalmia dominated sites in

11 Newfoundland. Growth and microsite characteristics around each seedling were also measured.

12 We found that normal and released seedlings had significantly higher proportions of ECM fungi

13 root tips than stunted seedlings supporting our final hypothesis but there was no significant

14 difference in distance between neighbours. Soil chemical properties are thought to inhibit the

15 vegetative spread of ECM fungi species in this particular system and are identified as an

16 important topic for further research. 


\section{Introduction}

In thick ericaceous heaths conifer seedlings/saplings often experience stunted growth

20 referred to as 'growth check'. In Sweden, extracts of Empetrum hermaphroditum L. litter have

21 been shown to interfere with the regeneration of Pinus sylvestris L. seedlings by reduced root

22 development, mycorrhizal colonization and $\mathrm{N}$ uptake (Nilsson et al. 1993). In western Canada,

23 Gaultheria shallon Purch has been reported to suppress conifer growth in clearcuts by out-

24 competing the tree seedlings for N and P (Messier 1993). Similarly, black spruce (Picea mariana

25 Mill. BSP) growth inhibition in the presence of ericaceous shrubs such as Kalmia angustifolia L.

26 (hereafter referred to as Kalmia) and Labrador tea (Rhododendron groenladnicum Oeder Kron et

27 Judd) has been reported from eastern and mid-Canada (Mallik 2001; Inderjit and Mallik 1996).

28 This phenomenon of tree seedling growth stunting is generally concomitant with a rapid growth

29 of the understory ericaceous plants after removal of canopy trees by forest fires or logging. The

30 post-disturbance dominance of ericaceous shrubs and poor tree seedling regeneration following

31 disturbances that remove the overstory canopy yet leave the soil relatively undisturbed may

32 cause vegetation shift form forest to heath (Mallik 2001). Kalmia exhibits vigorous vegetative

33 regrowth from basal sprouting and rhizomes; rhizomes may grow up to one metre in length in a

34 single growing season (Mallik 1993) and Kalmia can quickly dominate any suitable seedbed for

35 black spruce regeneration within the first four years after a fire (Mallik et al. 2010). Siegwart-

36 Collier and Mallik (2010) reported that successful germination and establishment of black spruce

37 seedlings require exposed mineral soil or thin post-fire residual organic matter up to $2 \mathrm{~cm}$,

38 conditions that are rare after low intensity forest fires or clearcuts.

This lack of suitable seedbed is reflected in the drastic reduction of black spruce stem

40 densities in Kalmia heaths. In a study conducted in eight post-fire heaths, the mean stem density 
41 of black spruce was found to be only 314 stems ha $^{-1}$, much lower than the 3000 stems ha $^{-1}$

42 required for canopy closure (Kravchenko 2012). However, some scattered black spruce seedlings

43 can be found in post-fire Kalmia heaths with variable growth but a large majority of seedlings

44 exhibit stunted growth. Krause et al. (2009) reported that the leader growth of juvenile black

45 spruce in naturally regenerating post-fire stands is an increase of at least $10 \mathrm{~cm}$ per year and this

46 can be used as a benchmark for the growth rate of normally growing trees. This growth rate of

47 black spruce is not commonly observed in a Kalmia heath. However, over time some previously

48 stunted black spruce seedlings may achieve this growth rate, a phenomenon call 'growth

49 release'. Past studies attributed various abiotic and biotic factors to inadequate black spruce

50 regeneration and poor growth in Kalmia heath such as limitation of suitable seedbeds (Mallik et

51 al. 2010), competition for limited soil N and P (Yamasaki et al. 2002) and allelopathy (Zhu and

52 Mallik 1994). However, the mechanism of growth release of stunted black spruce in Kalmia

53 heath remains unknown. It has been proposed that interactions with symbiotic fungi may be a

54 driving force behind the growth release (Johnson et al. 2006).

55 Plenchette et al. (1983) have shown that in nutrient poor systems, the removal of

56 mycorrhizal communities resulted in stunted growth of 16 different species and this growth

57 check was corrected by re-inoculation with fungi. It has been shown that some ECM fungal

58 species may be inhibited by Kalmia allelochemicals (Mallik and Zhu 1993; Yamasaki et al.

59 1998) leading to a deprivation of nutrients to the host, while the growth of other ECM fungi

60 species may be stimulated as they utilize the phenolics as a carbon source (Zeng and Mallik

61 2006). The metabolizing of phenolics by ECM fungi reduces their concentration in the soil and

62 lessens the inhibitory effect they have on black spruce root growth. The degree to which ECM

63 fungi play a role in black spruce growth release in Kalmia dominated heaths is unknown. 
Vegetative growth by mycelia can be classified into three broad categories: short,

65 medium and long-range exploration mycelia, based on how far from the inoculum source a

66 particular species may extend their mycelia to capture nutrients (Agerer 2001) and to colonize

67 new root tips (Peay et al. 2011). The distribution and composition of ECM fungi communities

68 depend on both biotic and abiotic factors (Nikonov et al. 2006). Other studies have shown that

69 composition and abundance of ECM fungi are dependent on the abundance of host plants

70 (Piotrowski et al 2008) and their root density (Peay et al. 2011). Because host plants influence

71 microsite soil chemistry and provide habitat for ECM fungi, their growth and distribution in the

72 system should reflect the composition and distribution of local ECM fungi (Aponte et al. 2013).

73 Based on the dendrochronology of black spruce seedlings in eight post-fire Kalmia heaths in

74 Newfoundland, Kravchenko (2012) identified three distinct growth forms of black spruce:

75 stunted, released and normal. From a positive correlation between the seedling height and

76 microsite organic matter depth he speculated that with time increased ECM fungi abundance in

77 the organic matter might help initiate the growth release of black spruce seedlings.

The benefits imparted by an ECM symbiotic relationship are numerous and this study

79 aimed to determine if they were sufficient to initiate a growth release in stunted seedlings.

80 Because the abundance and density of any particular ECM fungi species depends partly on its

81 ability to disperse through soil from host to host, we assumed that a spatial pattern should exist

82 among trees showing stunted, released and normal growth that reflects the degree to which their

83 roots have been colonized. We hypothesised that i) a maximum lateral distance exists between

84 inoculum source and new host (i.e. neighbouring seedlings) over which the local ECM fungi can

85 spread to initiate a growth release, ii) soil microsite variables around normal and released

86 seedlings would be more favorable to black spruce seedling growth and the spread of ECM 
87 fungi, and iii) ECM fungi abundance will be higher in normal and released seedlings than stunted

88 ones because their presence help the host seedlings acquire limited essential nutrients.

90 Materials and Methods

91 Study area and sites

92 We conducted this study in Terra Nova National Park in the Central Newfoundland

93 ecoregion of the Boreal Shield ecozone. Here average January and July temperatures vary from -

$9414^{\circ}$ to $-10^{\circ} \mathrm{C}$ and $11^{\circ}$ to $15^{\circ} \mathrm{C}$ respectively (Natural Resource Canada 2011). The area receives

95801 to $1200 \mathrm{~mm}$ average annual precipitation, of which approximately $30 \%$ is snowfall. The

96 soils of the area are nutrient poor podzolic gravel-loam (Agriculture and Agri-Food Canada

97 1998). The study sites were 18 yr-old Spracklin Road (SR) burn (GPS 48.5577502 -54.0311050)

98 and 31 yr-old Charlottetown (CT) burn (GPS 48.4508143 - 54.0056102) at $107 \mathrm{~m}$ a.s.1. Previous

99 to fire, both sites were dominated by black spruce with Kalmia as the main understory species.

100 Bloom (2001) determined fire severity indices (pre-fire drought code, burn days) were similar in

101 both sites: 446 for SR burn and 412 for CT burn (Table 1). After fire both sites turned into

102 Kalmia heath interspersed with black spruce and larch (Larix laricina Koch) seedlings and

103 saplings. Other ericaceous shrubs such as Rhododendron canadense L. and $R$. groenlandicum

104 were subordinate to Kalmia. Ground vegetation was dominated by pleurocarpous mosses such as

105 Pleurozium schreberi Brid. Mitt. and Dicranum polysetum Swartz, and fruticose lichens such as

106 Clintonia borealis Aiton. Raf. and Cladina rangiferina L. Both study sites were naturally

107 regenerating after fire and experiencing the same climatic conditions as they are geographically

108 close to one another. The sites experienced no other disturbance since the last fire and varied 
109 only in time since last fire and organic matter depth (Table 1). Stunted and released seedlings

110 were present in both sites.

111 Pre-and post-fire black spruce stem density

112 The black spruce stem densities for each site were recorded as well as those of other

113 trees, which may act as alternate hosts for ECM fungi. Pre-fire black spruce stem densities were

114 obtained from L. Siegwart-Collier based on densities in adjacent unburned stands (unpublished

115 data). Post-fire stem densities were obtained by counting stems in a $100 \mathrm{~m}^{2}$ area around each

116 focal seedling/sapling (described below) and converting to stems ha ${ }^{-1}$. Black spruce seedlings of

117 same age can achieve different size because of growth differences, larger ones are saplings but

118 hereafter for simplicity we use seedlings to refer both seedlings and saplings.

\section{Seedling growth measurement}

We measured $22+9$ stunted, $19+7$ released, and $2+11$ normally grown black spruce

121 seedlings from the Charlottetown (CT) and Spracklin Road (SR) study sites respectively. From

122 each seedling we obtained a stem disc at the ground level to measure annual ring growth

123 increments. In the laboratory we used WinDENDRO software (Regent Instruments, Canada) to

124 calculate the annual ring widths. Mean ring width of the previous five years was taken to account

125 for variations in year-to-year climate, which may have affected growth. Stem discs were also

126 used to assess the age of each tree. After the mycorrhizal and non-mycorrhizal root counting the

127 root samples were placed in an oven at $103{ }^{0} \mathrm{C}$ for $24 \mathrm{hrs}$ and mean oven dry weight of root

128 biomass was recorded for each seedling.

129 Seedling microsite characteristics 
$131 \mathrm{~m}$ quadrat to determine if the site conditions around the seedlings are associated with

132 colonization of ECM fungi and the potential release of the seedlings. We recorded \% cover of

133 Kalmia and $R$. canadense because they were the most dominant plants in the community. We

134 measured soil temperature, soil moisture and conductivity, $48 \mathrm{hrs}$ after rainfall using a W.E.T.

135 Sensor HH2 moisture metre (Delta-T Devices, Cambridge, England) at three locations along a

136 diagonal line spanning the corners of the plot. This sensor measures the three parameters of the

137 soil in direct contact with the probes, to a depth of $7 \mathrm{~cm}$. Soil $\mathrm{pH}$ was also measured in three

138 locations in 1:1 soil-water ratio using a portable $\mathrm{pH}$ metre (Spectrum Technologies Inc., U.S.A.).

139 We measured organic matter depth at the time of soil core extraction (described below) to a

140 maximum depth of $35 \mathrm{~cm}$.

141 Extraction of mycorrhizal and non-mycorrhizal roots

142 Three soil cores were collected from under each tree's canopy using a $40 \mathrm{~cm}$ long, 5.5

$143 \mathrm{~cm}$ diameter Eijkelkamp split tube sampler (Hoskin Scientific, Burlington, Ontario). Cores were

144 obtained as far down as mineral soil if possible. Each soil core was placed in a labelled re-

145 sealable plastic bag. In the laboratory the cores were soaked for $24 \mathrm{hrs}$ to facilitate separation of

146 roots from the soil mass. Then black spruce roots were extracted by gently washing and rubbing

147 the soil cores under slow running water over a sieve and then placed in another re-sealable bag.

148 Any remaining rhizosphere soil and unrelated roots were removed under a dissection microscope

149 at $25 \times$ magnification. The black spruce root samples were kept at $4{ }^{\circ} \mathrm{C}$ until identification of

150 ECM fungi species.

151 Identity, diversity and abundance of ECM fungi. 
153 and examined using a dissection microscope at $25 \times$ and $40 \times$ magnification. Initial identification

154 was performed using morphological characteristics including colour, ramification, presence and

155 structure of rhizomorphs and emanating hyphae, appearance of the mantle, autofluorescence

156 under UV light, and the detection of a chemical colour change in the presence of aqueous $\mathrm{FeSO}_{4}$

157 and/or a $10 \% \mathrm{KOH}$ aqueous solution. This process resulted in the assignment of ECMs to nine

158 morphotype groups, labelled A-J (letter E was assigned to uncolonized root tips as a control).

159 Once identification of the morphotype groups was complete, we counted the mycorrhizal and

160 non-mycorrhizal root tips systematically for each root from left to right of the dish. We recorded

161 the mean number of mycorrhizal and non-mycorrhizal root tips from three soil cores around each

162 seedling.

163 A minimum of three samples of each identified morphotype was collected for molecular

164 identification. Fungal DNA was extracted from the root tips using a DNeasy Plant Mini Kit

165 (Qiagen, Valencia, CA, USA). DNA amplification and sequencing was performed in the Paleo-

166 DNA lab at Lakehead University. The internal transcribed spacer 2 (ITS2) region was chosen as

167 the target for amplification for both the soil and root tip DNA samples. Of the published primers

168 targeting the fungal ITS region, none were outstanding, or outperformed the others, so custom

169 forward (5' - CCTTGGTATTCCGAGGAGC - 3') and reverse (5' -

170 CGTGTCAAAGACGGGATT - $3^{\prime}$ ) primers were designed at the Paleo-DNA lab of Lakehead

171 University. The optimal annealing temperature of $60^{\circ} \mathrm{C}$ was determined for the primers by

172 running a gradient PCR. For all samples, the PCR amplification mixture included: $3 \mu 1$ DNA

173 template, $2.5 \mathrm{nmol}$ of each primer, $12.5 \mu$ Accustart $^{\mathrm{TM}}$ II PCR SuperMix (Quanta Biosciences,

174 Gaithersburg, MD, USA), and distilled deionized water for a total volume of $25 \mu 1$. The 
175 Accustart mix includes Taq DNA polymerase for a 'hot start' PCR. The thermocycling program

176 for the Eppendorf Mastercycler thermocycler included an initial denaturation step at $96{ }^{\circ} \mathrm{C}$ for 2

177 minutes, followed by 50 cycles of $94{ }^{\circ} \mathrm{C}$ for $30 \mathrm{~s}, 60{ }^{\circ} \mathrm{C}$ for $1 \mathrm{~min}$, and $72{ }^{\circ} \mathrm{C}$ for $2 \mathrm{~min}$, with the

178 lid temperature held at $105{ }^{\circ} \mathrm{C}$ throughout. Successful amplification was confirmed in $2 \%$

179 agarose gels stained with ethidium bromide. Soil samples that failed to amplify were subjected to

180 an additional silica bead/guanidine thiocyanate purification protocol before repeating the PCR

181 protocol.

182

Amplified DNA products were purified with the QIAquick PCR Purification Kit

183 (Qiagen), and the ExoSAP-IT PCR Product Cleanup (Affymetrix, Santa Clara, CA, USA) for

184 root tip DNA. An aliquot of $3 \mu 1$ purified DNA template was labeled with BigDye Terminator

185 Cycle v3.1 Sequencing Kit, and sequenced on a 16-capillary ABI PRISM 3130x1 genetic

186 analyzer (Applied Biosystems, Foster City, CA, USA). All sequences were visually inspected

187 and machine errors manually edited with SEQUENCHER software (v5.3; Gene Codes

188 Corporation, Ann Arbor, MI, USA) before carrying out BLASTn searches on the NCBI and

189 UNITE online sequence databases (Appendix I). Multiple alignments were carried out using

190 MAFFT v.7.211 (Katoh 2013) with default options, and viewed with Seaview v4.5.4 (Guoy et al.

191 2010), to verify that the ITS2 region was being amplified by confirming the presence of the

192 adjacent highly conserved 5.8S region in each sequence.

193 Spatial pattern of stunted, released and normal seedlings

194 We used a randomized complete block design to select the specimen seedlings for this

195 study with the two sites as blocks. Within each site we placed three $150 \mathrm{~m}$ transects at random

196 bearings at least $25 \mathrm{~m}$ between the two adjacent transects. At every $15 \mathrm{~m}$ along each transect we 
197 sought a black spruce seedling within a 10 m radius; that black spruce seedling was selected as

198 the focal seedling. If no black spruce was found at a point the process continued on to the next 15

199 m of the transect until 10 focal black spruce seedlings were selected per transect. Each focal

200 black spruce seedling was assigned a growth type (normal, released or stunted) based on its

201 appearance (height, inter-nodal distance and length of current year's leader; (Krause et al.

202 2009)). In a $5.6 \mathrm{~m}$ radius around each focal seedling, all other black spruce seedlings were

203 considered as neighbours and assigned growth type; the distance from the focal seedling was

204 measured and their growth characteristics recorded. The presence of balsam fir (Abies balsamea

205 L.) and birch (Betula spp.) as neighbours was avoided in this assessment because many of them

206 had been browsed heavily by moose (Alces alces L.) and above ground herbivory would affect

207 below ground growth and therefore the magnitude of colonization by ECMs (Piippo et al. 2011).

208 Therefore, the presence of their roots in soil cores was deemed to be unlikely. We initially

209 considered L. laricina seedlings as they may act as potential alternate hosts for ECM fungi.

210 However, the morphological distinction of roots belonging to P. mariana and L. laricina was

211 difficult and therefore all spruce focal trees that had a larch neighbour were removed from the

212 sample set. This deletion of soil cores from the dataset was performed only after we had detected

213 the presence of host specific ECM fungi associated with L. laricna.

\section{Statistical analysis}

215 We used one-way ANOVA on the distance between neighbours, their mean colonization

216 and the time interval between release events for the focal seedling and its neighbour, followed by

217 a Tukey post hoc test to determine if there was a significant difference between the four seedling

218 growth relationship types (normal-released, released-released, released-stunted, stunted-stunted).

219 Separate ANOVAs were performed followed by Tukey post hoc tests to determine if any 
220 significant difference existed among the three black spruce seedling growth types (normal,

221 released and stunted) in terms of percentage of mycorrhizal root tips, annual ring width, oven dry

222 weight of root mass extracted and microsite variables (organic matter depth, soil pH, moisture,

223 and temperature). Square root transformations were performed to meet assumptions of normality

224 for annual ring width and mycorrhizal root tips. All statistical tests were performed using R

225 version 2.15.3 (R Core Team, 2013).

227 Results

228 Pre- and post-fire black spruce stem densities

229 Black spruce stem densities in both sites dropped considerably after fire (Table 1). The

230 SR site had lower overall black spruce stem density but a higher proportion of normal and

231 released seedlings than the CT site (Figure 1).

\section{Seedling growth measurement}

For the SR site, normal and released seedlings had significantly higher annual ring widths 234 than stunted seedlings ( $\mathrm{p}=0.01,0.004$ respectively) and the same held true for the CT site $(\mathrm{p}=$

$2350.04,4.5 \times 10^{-4}$ respectively). Significant difference in annual ring width was found between

236 normal and released seedlings in the SR site, but not the CT site (Table 2). When the growth

237 types are compared between the sites, released seedlings in the CT site had a significantly higher

238 annual ring width than released seedling in the SR site $(\mathrm{p}=0.01)$. Correlation between annual

239 ring width and seedling growth type justified assignment of growth type based on physical 
240 appearance of the seedling (Pearson correlation coefficient, $r=0.455$ ). We found no significant

241 difference in age or root dry weights among the seedling growth types (Table 2).

242 Seedling growth, ECM colonization and microsite characteristics

243 Within each site, microsite characteristics varied little among normal, stunted and

244 released seedlings. Organic matter depth, and soil $\mathrm{pH}$, moisture, and temperature were similar in

245 the area surrounding each seedling (Table 2). There was also no significant difference in \% cover

246 of Kalmia among the seedling growth types for either site. Normal seedlings had significantly

247 higher ECM fungi colonization $\left(\mathrm{p}=3.8 \times 10^{-5}\right)$ and annual ring width $\left(\mathrm{p}=7.6 \times 10^{-4}\right)$ than

248 stunted seedlings. The same trend held for released seedlings having higher ECM colonization ( $p$

$\left.249=1.2 \times 10^{-6}\right)$ and annual ring width $\left(\mathrm{p}=2.3 \times 10^{-6}\right)$ than stunted seedlings (Table 2). Both normal

250 and released seedlings of the CT site had higher ECM fungi colonization than the normal and

251 released seedlings in the SR site $(\mathrm{p}=0.03)($ Table 2$)$.

\section{Identity, diversity and abundance of ECM}

253 We analysed ECM fungi root tips for 13 normal, 26 released, 31 stunted black spruce

254 seedlings for a total of 17550 fungal root tips. Due to the cryptic nature of ECMs, the

255 assignment of morphotypes to groups labelled A and B included a total of 5 species of the genus

256 Cortinarius. Samples included in morphotype groups H and I encompassed two species of the

257 Lactarius genus. Therefore, root tip counts for those morphotype groups were combined and all

258 analyses were performed at the genus level. One morphotype was identified as Sullius cavipes

259 which is thought to exclusively form on the roots of L. laricina, and very occasionally Pinus

260 sylvestris L. (Finlay 1989). Therefore all soil cores containing that morphotype were removed

261 from the data set so as to not include L. laricina roots in the analysis. The genus Leccinium is 
262 thought to be composed of mostly host-specific species that form associations with trees mainly

263 belonging to Betulacaea, Salicacaea, and Fagacaea, although Leccinium piceinum, was reported

264 to form associations with Picea spp. (den Bakker et al. 2004). Our study sites contained little or

265 no Populus sp. and Betula sp. and so the presence of their roots in our soil cores is very unlikely.

266 Abundances of all genera showed no clear trend among the growth sites, or within growth types

267 between sites. The wide range of ECM fungi colonization observed in individual seedlings made

268 the differences non-significant (Table 4). There was a significant difference in which genera

269 were most abundant between sites, with Cortinarius being most abundant in normal seedlings in

270 the younger SR site and Tylospora being most abundant in released seedlings in the older CT

271 site.

272 Spatial patters of stunted, released and normal seedlings

273 The selection of a released neighbour within $5.6 \mathrm{~m}$ of the focal seedling resulted in 33

274 focal seedling-neighbour relationships with the other 17 focal seedlings lacking a black spruce

275 neighbour, reflecting the poor recruitment of black spruce in the post-fire Kalmia heath. Due to

276 low sample sizes within sites, samples were pooled for both sites. Seedlings in normal-released

277 pairs had significantly higher colonization rates than those in a stunted-stunted pair (Table 3).

278 When considering the distance separating two individuals in a growth type pair, we found no

279 significant difference among any growth type pair $(\mathrm{p}=0.47)($ Table 3$)$. We did however find a

280 significant difference between the growth type pairs in the years between release events. We

281 considered only two growth type relationships (released - released and released - stunted) for this

282 comparison because normal seedlings would not experience release and there are no release

283 events to consider in a stunted - stunted pair. For a released - released pair, both release events

284 occurred within approximately two years of each other; in a released - stunted pair, we observed 
285 a significantly higher time interval $(\mathrm{p}=0.03)$ in which the second release event has yet to occur

286 Mean organic matter depth did not vary significantly between relationship pairs (Table 3).

Discussion

Growth release of black spruce seedlings observed in Kalmia heath appears to be linked to the percentage of ECM fungi colonization of their root system, which supports our third and

291 main hypothesis (Table 2). As predicted, the normal seedlings had a higher percentage of their

292 root tips colonized by at least one type of ECM and this trend holds for the released seedlings as

293 well. Higher levels of ECM fungal colonization are associated with favourable seedling growth

294 and this is evident in the annual ring widths of normal and released seedlings having wider 295 annual rings (Table 2).

297 creates a seedbed filter and the strength of the filter is dependent on its thickness. The SR site is 298 characterized by lower OM depth $(5 \mathrm{~cm})$ compared to the CT site $(15 \mathrm{~cm})$. Black spruce seeds 299 germinating in the SR site would have experienced better initial growing conditions than those in 300 the CT site with thicker OM. This is reflected in the higher proportion of stunted seedlings in the 301 CT site (Fig. 1), which can be interpreted as a lower number of germination safe sites (Harper 302 1977). One can conclude from this that overall black spruce growth would be better in an area 303 that has a more suitable seedbed for germination and lower amounts of allelopathic phenolics 304 (i.e., lower OM depth and lower Kalmia litter) however this is not the case here. The CT site had 305 higher OM depth and Kalmia cover than SR site (15 cm vs. $5 \mathrm{~cm}$ and $44 \%$ vs. 30\% respectively;

306 Table 1), which are conditions that are less favourable for black spruce seedling growth.

307 However, this site also possesses characteristics that favour the growth and colonization of ECM 
308 fungi, such as higher densities of potential hosts (black spruce seedlings), thicker OM allowing

309 for niche differentiation among ECM species (Bahram et al. 2015) and a longer time since fire.

310 The normal and released seedlings of the CT site, although lower in numbers (Fig. 1), possess

311 higher rates of colonization than those in the SR site, and also exhibit similar if not significantly

312 higher annual growth increments (Table 2). So while conditions in the CT site may be more

313 severe for black spruce in the beginning, if a high percentage of their roots are colonized by

314 ECM fungi, the characteristics of the site (which favour ECM fungi development) determine that

315 the benefits imparted by ECM fungi are greater than the inhibition imposed by Kalmia phenolics.

Another interpretation that leads to a similar conclusion is that lower colonization rates in a

317 site which has more favourable growing conditions is that the host seedlings are resisting

318 infection by fungal mycelia, as this has been shown in many systems. It has been shown that

319 carbohydrate allocation to fungal symbionts might be regulated by the host based on nutrient

320 availability (Wright et al. 2000; Nehls et al. 2007). Trees growing in harsh conditions may

321 allocate more photosynthates to symbionts and they are rewarded with better growth because of

322 increased ECM fungi colonization. Those growing in less stressful conditions may not supply as

323 much carbohydrate to their mycorrhizae; a trade-off between photosynthate retention and soil

324 nutrient uptake that results in lower growth rates. Regardless of the events leading to

325 colonization, we observe better seedling growth in conditions which should be more inhibiting,

326 but only in seedlings which experience high ECM fungi colonization rates ( $>50 \%)$, leading us to

327 conclude that the benefits imparted to black spruce by ECM fungi in a Kalmia dominated heath

328 are indeed positive but that the magnitude of the benefit is site dependent. It is important to note

329 that the improved growth of individual black spruce through ECM fungal colonization does not

330 wholly solve the problem of poor recruitment in Kalmia heaths. Even if every seedling 
331 experienced a release event, stem densities would still be insufficient for canopy closure, a fact

332 that is related to safe site limitations immediately after fire (Kravchenko 2012).

Despite the evidence that ECM fungi colonization is a driving force in the growth of

334 seedlings in heaths, there was no significant difference in the distance that separated two

335 individuals of a growth type pair (Table 3). The first hypothesis that a pattern exists among black

336 spruce seedlings of the three growth types (normal, released and stunted) and should be reflected

337 in their ECM fungi community was not supported. Therefore, we cannot conclude that proximity

338 to an inoculum source alone drives colonization of ECM fungi in black spruce seedlings in a

339 Kalmia dominated heath. This is contrary to other studies showing that neighbouring trees or

340 shrubs act as sources of inoculum and increases the chance of colonization of an individual by

341 ECM fungi (Cline et al. 2005; Hubert and Gehring 2008; Bai et al. 2009).

342 One could speculate that the seedlings in a released - released relationship once existed as

343 a released - stunted relationship and that the distance between them was eventually covered by

344 ECM fungi to initiate the release of the stunted seedling. This is not an unreasonable assumption

345 as multiple studies have shown how mycorrhizal species richness and abundance increases with

346 time following a disturbance (e.g. Smith et al. 2002), including this study where the seedlings in

347 the older site had higher percentages of root tips being mycorrhizal (Table 2). The similarity in

348 the mean distances between neighbours of any relationship (Table 3) could suggest that either i)

349 time is a factor and that stunted seedlings within an approximate $5.6 \mathrm{~m}$ radius are more likely to

350 experience a release event in the near future or that ii) some other factor(s) exist that inhibit the

351 colonization of a stunted seedling despite its proximity to a released neighbour. When

352 considering the time interval between the release events (Table 3), the release events between

353 released - released pair occurred within a shorter time frame than a released - stunted pair. For 
354 released - stunted pairs, assuming that the time interval between the release events is open-ended,

355 we see a mean time of approximately four years in which a second release event has yet to occur.

356 The similarity in distance between individuals, accompanied by dissimilarity in time between

357 release events, lends more weight to the argument that microsite conditions, rather than time, are

358 exerting an influence on ECM fungi dispersal. Microsite conditions may create this time lag by

359 slowing or inhibiting the spread of fungal mycelia.

360 Root mass potential of host seedlings influences ECM colonization because of varying 361 strategies of vegetative growth in ECM fungi. Those with contact or short exploration types, 362 sensu Agerer (2001) (i.e. limited vegetative spread), are restricted to areas where root density is

363 high whereas the ones with extensive hyphal spread are better able to disperse from the source of 364 inoculum to colonize other seedlings. This is an important trait as above ground black spruce 365 stem density of the study areas dropped from 5100 and 3240 stems ha $^{-1}$ (L. Siegwart-Collier, 366 unpublished data) to 188 and 273 stems ha $^{-1}$ measured 18 and 31 yrs after fire respectively in the 367 two sites (Fig. 1), meaning that host root availability for ECM fungi colonization also dropped.

368 Four out of six genera identified are described as being medium (Cortinarius, Piloderma,

369 Tomentellopsis) - or long-range (Leccinum) exploration type, the remaining two (Tylospora and

370 Lactarius) are described as being contact or short distance exploration types (Agerer 2001). Long

371 range foraging and reproduction may reflect an ideal strategy when hosts are sparse and

372 separated by long distances. Indeed, Lactarius ECM were only found on trees with a neighbour

373 within the $5.6 \mathrm{~m}$ radius. Yet consideration must be given to the lack of a spatial pattern of

374 colonization rates among neighbouring seedlings reported, suggesting that even if a host is close

375 by, dispersal may still be inhibited. 
Therefore, soil environment becomes the determining factor of whether or not mycelia of

377 ECM fungi can spread to colonize a new host should a potential host be present within the

378 theoretical range of ECM fungi mycelia, which can be up to several decimetres (Agerer 2006).

379 The second hypothesis that microsite conditions influenced the abundance of ECM fungi root

380 tips was also not supported because we found no significant difference in the soil variables

381 measured around the seedlings (Table 2). ECM fungal vegetative growth is dependent on factors

382 such as nutrient availability and pH (Wallander et al. 1999), and concentration of allelochemicals

383 (Mallik and Zhu 1993). Toljander et al. (2006) showed that plant litter chemistry significantly

384 influences the distribution of ECM fungi in soil and Joanisse et al. (2008) showed that Kalmia

385 litter increased the amounts of nitrogen sequestered as tannin-protein complexes, making

386 nitrogen more readily available to its own ericoid mycorrhizae and less to those ECM fungi

387 associated with black spruce. Yamasaki et al. (1998) showed that Kalmia phenolics may inhibit

388 the colonization of ECM fungi in black spruce and this restriction by Kalmia litter may make it

389 difficult or even impossible for ECM fungi to expand their mycelia and colonize new hosts.

390 Conversely, Zeng and Mallik (2006) showed that the growth of the ECM Paxillus involutus was

391 stimulated by the presence of Kalmia phenolics, highlighting a contrasting response among ECM

392 fungal groups to the phenolic acids found in the soil.

Although genera identified in this study were not among those used in studies examining

394 ECM growth in the presence of Kalmia, Cortinarius and Piloderma are among taxa listed as

395 being able to utilize proteins as a source of $\mathrm{N}$ in nitrogen poor conditions (Lilleskov et al. 2002).

396 This would provide a significant competitive advantage if they were able to access sequestered

397 organic nitrogen in the form of protein-tannin complexes. Also, it has been suggested by

398 Clemmensen et al. (2015) that ECM fungi producing rhizomorphs (i.e. medium- and long-range 
399 exploration types) such as Cortinarius and Piloderma use $\mathrm{N}$ more efficiently as they are able to

400 recycle their mycelial necromass. The results of this study support this idea as Cortinarius and

401 Piloderma are the two most abundant ECM on all three growth types whereas Lactarius,

402 characterized by a lack of rhizomorphs and by the inability to use protein or its necromass as an

$403 \mathrm{~N}$ source, is the least abundant (Table 4). For this reason, it is thought that microsite

404 characteristics not accounted for (phenolic content, nutrient status) might influence the

405 vegetative growth of ECM fungi and the abundance of ECM fungal root tips in black spruce. The

406 high phenolic content and low nutrient levels of Kalmia heath soils may be acting as a filter, and

407 thus be responsible for the relatively low ECM species richness found in our study compared to

408 studies conducted in other boreal systems (Robertson et al. 2006). Alternatively, it could be a

409 result of low overstory tree species diversity, which has been shown to influence ECM fungal

410 diversity (Kernaghan et al. 2003). Since we used a custom designed primer, it is possible that it

411 did not amplify ascomycetes ITS regions, explaining their absence in the data. However,

412 considering that ascomycetes are reported as being low in abundance despite their common

413 occurrence (Robertson et al. 2006; Kernaghan et al. 2003), we may assume that their

414 contribution to growth release is not as important as basidiomycetes. Nonetheless, we

415 acknowledged this shortcoming and suggest that the use of the universal primer ITS1-F (Gardes

416 and Bruns 1993), instead of our custom designed primer, might have detected ascomycetes

417 sequences in some of our root tip samples.

419 Conclusions 
421 natural regeneration of black spruce. Regardless of the specific mechanisms of inhibition

422 involved, the environmental conditions of a Kalmia dominated heaths result in low black spruce

423 recruitment and the majority of the recruited seedlings exhibit stunted growth at some point in

424 their lives. We found evidences that support the view that black spruce seedling growth release is 425 associated with higher ECM fungi colonization. An abundance-distribution pattern of the 426 ectomycorrhizal community in relation to black spruce growth could not be detected. However, 427 importance of ECM fungi to black spruce in Kalmia heaths is a significant factor. Soil properties 428 which limit or promote ECM fungi vegetative spread should be studied in depth on a per species 429 basis to identify which ECM fungi are best suited to ericaceous soils. This will in turn facilitate 430 the restoration of black spruce forests in Kalmia heaths.

\section{Acknowledgements}

433 This study was supported by a Natural Science and Engineering Research Council

434 (NSERC) of Canada Discovery Grant (\# RGPIN-2014-06239) awarded to A.U.M. We thank the 435 staff of Terra Nova National Park for providing accommodation and logistical support during the 436 fieldwork, Dr. Helen Wagner for assistance in the experimental design, Dr. Shekhar Biswas for 437 comments on an earlier version of the manuscript, and Lindsey Maendel for assistance with 438 DNA sequencing. 


\section{References}

Agerer, R. 2001. Exploration types of ectomycorrhizae. Mycorrhiza, 11: 107-114. doi: $10.1007 / \mathrm{s} 005720100108$.

Agerer, R. 2006. Fungal relationships and structural identity of their ectomycorrhizae. Mycological Progress, 5: 67-107. doi:10.1007/s11557-006-0505-x.

griculture and Agri-Food Canada. 1998. Canadian Soil Classification System. Agri-Food Canada Publication 1646, NRC Press, 187 pp.

Aponte, C., García, L.V., and Marañón, T. 2013. Tree species effects on nutrient cycling and soil biota: A feedback mechanism favouring species coexistence. Forest Ecology and Management, 309: 36-46. doi:10.1016/j.foreco.2013.05.035.

Bahram, M., Peay, K.G., and Tedersoo, L. 2015. Local-scale biogeography and spatiotemporal variability in communities of mycorrhizal fungi. New Phytologist, 205: 1454-1463. doi:10.1111/nph.13206

Bai, S.-L., Li, G.-L., Liu, Y., Dumroese, R. K., and Lv, R.-H. 2009. Ostryopsis davidiana seedlings inoculated with ectomycorrhizal fungi facilitate formation of mycorrhizae on Pinus tabulaeformis seedlings. Mycorrhiza, 19:425-434. doi: 10.1007/s00572-009-02452.

Bloom, R. G. 2001. Direct and indirect effects of post-fire conditions on successional pathways and ecological processes, in black spruce-Kalmia forests. M. Sc. Thesis, Department of Biology, Lakehead University, Thunder Bay, Ontario.

Burgess, T. I., Malajczuk, N. and Grove, T. 1993. The ability of 16 ectomycorrhizal fungi to increase growth and phosphorus uptake of Eucalyptus globulus Labill. and E. diversicolor F. Muell. Plant and Soil, 153: 155-164. doi:10.1007/BF00012988. 
Clemmensen, K.E., Finlay, R.D., Dahlberg, A., Stenlid, J., Wardle, D.A., and Lindahl, B.D., 2015. Carbon sequestration is related to mycorrhizal fungal community shifts during long-term succession in boreal forests. New Phytologist, 205:1525-1536. doi:10.1111/nph.13208.

Cline, E. T., Ammirati, J. F., and Edmonds, R. L. 2005. Does proximity to mature trees influence ectomycorrhizal fungus communities of Douglas-fir seedlings? New Phytologist, 166: 993-1009. doi: 10.1111/j.1469-8137.2005.01387.x.

Corcobado, T., Vivas, M., Moreno, G., and Solla, A., 2014. Ectomycorrhizal symbiosis in declining and non-declining Quercus ilex trees infected with or free of Phytophthora cinnamomi. Forest Ecology and Management, 324: 72-80.

doi:10.1016/j.foreco.2014.03.040.

Damman, A. W. H. 1971. Effect of vegetation changes on the fertility of a Newfoundland forest site. Ecological Monographs, 41: 253-270. doi: 10.2307/1942368.

den Bakker, H.C., Zuccarello, G.C., Kuyper, T.W., and Noordeloos, M.E. 2004. Evolution and host specificity in the ectomycorrhizal genus Leccinum. New Phytologist, 163, 201-215. doi:10.1111/j.1469-8137.2004.01090.x.

Druebert, C., Lang, C., Valtanen, K., and Polle, A. 2009. Beech carbon productivity as driver of ectomycorrhizal abundance and diversity. Plant, Cell \& Environment, 32: 992-1003. doi:10.1111/j.1365-3040.2009.01983.x

Finlay, R.D. 1989. Functional aspects of phosphorus uptake and carbon translocation in incompatible ectomycorrhizal associations between Pinus sylvestris and Suillus grevillei and Boletinus cavipes. New Phytologist, 112, 185-192. doi: 10.1111/j.14698137.1989.tb02373.x. 
Gardes, M., and Bruns, T. D. 1993. ITS primers with enhanced specificity for basidiomycetes application to the identification of mycorrhizae and rusts. Molecular Ecology, 2, 113-118. doi: 10.1111/j.1365-294X.1993.tb00005.x.

Harper, J. 1977. Population Biology of Plants. Academic Press, London.

Hubert, N. A., and Gehring, C. A. 2008. Neighboring trees affect ectomycorrhizal fungal community composition in a woodland-forest ecotone. Mycorrhiza, 18: 363-374. doi: $10.1007 / \mathrm{s} 00572-008-0185-2$.

Inderjit and Mallik, A.U. 1996. Growth and physiological responses of black spruce (Picea mariana) in sites dominated by Ledum groenlandicum. Journal of Chemical Ecology, 22: $575-585$.

Joanisse, G. D., Bradley, R. L, Preston, C.M., and Bending, G.D. 2008. Sequestration of soil nitrogen as tannin-protein complexes may improve the competitive ability of sheep laurel (Kalmia angustifolia) relative to black spruce (Picea mariana). New Phytologist, 181: 187-198. doi: 10.1111/j.1469-8137.2008.02622.x.

Johnson, N.C., Hoeksema, J.D., Bever, J. D., Chaudhary, V. B., Gehring, C., Klironomos, J., Koide, R., Miller, R.M., Moore, J., Moutoglis, P., Schwartz, M., Simard, S., Swenson, W., Umbanhowar, J., Wilson, G., and Zabinski, C. 2006. From Lilliput to Brobdingnag: extending models of mycorrhizal function across scales. Bioscience, 56: 889-900. doi: 10.1641/0006-3568(2006)56[889:FLTBEM]2.0.CO;2.

Kernaghan, G., Widden, P., Bergeron, Y., Légaré, S., and Paré, D. 2003. Biotic and abiotic factors affecting ectomycorrhizal diversity in boreal mixed-woods. Oikos, 102: 497-504. doi:10.1034/j.1600-0706.2003.12415.x. 
Kravchenko, D. 2012. Role of safe sites in black spruce recruitment and growth release in postfire Kalmia heath. M. Sc. thesis, Department of Biology, Lakehead University, Thunder Bay, Ontario.

Kretzer, A. M., Dunham, S., Molina, R., and Spatafora, J.W. 2005. Patterns of vegetative growth and gene flow in Rhizopogon vinicolor and $R$. vesiculosus (Boletales, Basidiomycota). Molecular Ecology, 14: 2259-2268. doi: 10.1111/j.1365294X.2005.02547.x.

Krause, C., Morin, H., and Ploudre, P.-Y. 2009. Juvenile growth of black spruce (Picea mariana [Mill.] BSP) stands established during endemic and epidemic attacks by spruce budworm (Choristoneura fumiferana [Clemens]) in the boreal forest of Quebec, Canada. The Forestry Chronicle, 85: 267-276.

Lilleskov, E.A., Hobbie, E.A., and Fahey, T.J., 2002. Ectomycorrhizal fungal taxa differing in response to nitrogen deposition also differ in pure culture organic nitrogen use and natural abundance of nitrogen isotopes. New Phytologist, 154: 219-231. doi:10.1046/j.1469-8137.2002.00367.x.

Mallik, A. U. 1993. Ecology of a forest weed of Newfoundland: vegetative regeneration strategy of Kalmia angustifolia. Canadian Journal of Botany, 71: 161-166.

Mallik, A. U. 2001. Black spruce growth and understory species diversity with and without sheep laurel. Agronomy Journal, 93: 92-98. doi: 10.2134/agronj2001.93192x.

Mallik, A. U., and Zhu, H., 1993. Overcoming allelopathic growth inhibition by mycorrhizal inoculation. ACS Symposium Series, 582: 39-57.

Mallik, A. U., Bloom, R. G., and Wisenant, S G. 2010. Seedbed filter controls post-fire succession. Basic and Applied Ecology, 11: 170-181. doi: 10.1016/j.baae.2009.11.005. 
Messier, C. 1993. Factors limiting early growth of western red cedar, western hem-lock, and sitka spruce seedlings on ericaceous-dominated clearcut site in coastal British Columbia. Forest Ecology Management, 60:181-206. doi: 10.1016/0378-1127(93)90080-7.

Natural Resource Canada. 2011. The Atlas of Canada. Online $<<$ http://atlas.nrcan.gc.ca/site/english/index.html $>>$ Accessed December 29, 2011.

Nehls, U., Grunze, N., Willmann, M., Reich, M., and Kuster, H. 2007. Sugar for my honey: Carbohydrate partitioning in ectomycorrhizal symbiosis. Phytochemistry, 68: 82-91. doi: 10.1016/j.phytochem.2006.09.024.

Nikonov, V. V., Lukina, N. V., Polyanskaya, L. M., Fomicheva, O. A., Isaeva, L.G., and Zvyagintsev, D. G. 2006. Population and biomass of microorganisms in soils of pyrogenic succession in the northern taiga pine forests. Eurasian Soil Science, 39: 484494. doi: 10.1134/S1064229306040107.

Nilsson, M.- C., Högberg, P., Zackrisson, O., and Fengyou, W. 1993. Allelopathic effects of Empetrum hermaphroditum on development and nitrogen uptake by roots and mycorrhizae of Pinus silvestris. Canadian Journal of Botany, 71: 620-628. doi: 10.1139/b93-071.

Peay, K, G., Kennedy, P. G., and Bruns, T. D. 2011. Rethinking ectomycorrhizal succession: are root density and hyphal exploration types drivers of spatial and temporal zonation? Fungal Ecology, 4: 233-240. doi: 10.1016/j.funeco.2010.09.010.

Piotrowski, J. S., Lekberg, Y., Harner, M. J., Ramsey, P. W., and Rillig, M. C. 2008. Dynamics of mycorrhizae during development of riparian forests along an unregulated river. Ecography, 31: 245-253. doi: 10.1111/j.0906-7590.2008.5262.x. 
Piippo, S., Markkola, A., Harma, E., and Tuomi, J. 2011. Do compensatory shoot growth and mycorrhizal symbionts act as competing above- and below-ground sinks after simulated grazing? Plant Ecology, 212: 33-42. doi: 10.1007/s11258-010-9799-5.

Plenchette, C., Fortin, J. A., and Furlan, V. 1983. Growth responses of several plant species to mycorrhizae in a soil of moderate P-fertility. I. Mycorrhizal dependency under field conditions. Plant and Soil, 70: 199-209. doi: 10.1007/BF02374780.

R Core Team. 2013. R: A language and environment for statistical computing. R Foundation for Statistical Computing, Vienna, Austria. ISBN 3-900051-07-0, URL http://www.Rproject.org/.

Robertson, S.J., Tackaberry, L.E., Egger, K.N., and Massicotte, H.B. 2006. Ectomycorrhizal fungal communities of black spruce differ between wetland and upland forests. Canadian Journal of Forest Research, 36: 972-985. doi:10.1139/x06-001.

Schützendübel, A. and Polle, A. 2002. Plant responses to abiotic stresses: Heavy metal-induced oxidative stress and protection by mycorrhization. Journal of Experimental Botany, 53: 1351-1365. doi: 10.1093/jexbot/53.372.1351

Siegwart-Collier, L. C. and Mallik, A. U. 2010. Does post-fire abiotic habitat filter create divergent plant communities in black spruce forests of eastern Canada? Oecologica, 164: 465-477. doi: 10.1007/s00442-010-1642-0.

Smith, J. E., Molina, R., Huso, M. M. P., Luoma, D. L., McKay, D., Castellano, M. A., Lebel, T., and Valachovic, Y. 2002. Species richness, abundance, and composition of hypogeous and epigeous ectomycorrhizal fungal sporocarps in young, rotation-age, and old-growth stands of Douglas-fir (Pseudotsuga menziesii) in the Cascade Range of Oregon, U.S.A. Canadian Journal of Botany, 80: 186-204. doi: 10.1139/B02-003. 
Toljander, J. F., Eberhardt, U., Toljander, Y. K., Paul, L. R., and Taylor, A. F. S. 2006. Species composition of an ectomycorrhizal fungal community along a local nutrient gradient in a boreal forest. New Phytologist, 170: 873-884. doi: 10.1111/j.1469-8137.2006.01718.x.

Van der Heijden, M. G. A., and Horton, T. R. 2009.Socialism in soil? The importance of mycorrhizal fungal networks for facilitation in natural ecosystems. Journal of Ecology, 97: 1139-1150. doi: 10.1111/j.1365-2745.2009.01570.x.

Wallander, H., Arnebrant, K., and Dahlberg, A. 1999. Relationships between fungal uptake of ammonium, fungal growth and nitrogen availability in ectomycorrhizal Pinus sylvestris seedlings. Mycorrhiza, 8: 215-223. doi: 10.1007/s005720050237.

Wright, D. P., Scholes, J. D., Read, D. J., and Rolfe, S. A. 2000. Changes in carbon allocation and expression of carbon transporter genes in Betula pendula (Roth.) colonized by the ectomycorrhizal fungus Paxillus involutus (Batsch) Fr. Plant, Cell and Environment, 23: 39-49. doi: 10.1046/j.1365-3040.2000.00518.x.

Yamasaki, S. H., Fyles, J. W., Egger, K. N., and Titus, B. D. 1998. The effect of Kalmia angustifolia on the growth, nutrition, and ectomycorrhizal symbiont community of black spruce. Forest Ecology and Management, 105: 197-207. doi: 10.1016/S03781127(97)00285-5.

Yamasaki, S. H., Fyles, J. W., and Titus, B. D. 2002. Interactions among Kalmia angustifolia, soil characteristics, and the growth and nutrition of black spruce seedlings in two boreal Newfoundland plantations of contrasting fertility. Canadian Journal of Forest Research, 32: 2215-2224. doi: 10.1139/X02-119.

Zeng, R. S., and Mallik, A. U. 2006. Selected ectomycorrhizal fungi of black spruce (Picea mariana) can detoxify phenolic compounds of Kalmia angustifolia. Journal of Chemical 
Ecology, 32: 1473-1489. doi: 10.1007/s10886-006-9063-6.

Zhu, H., and Mallik, A. U. 1994. Interactions between Kalmia and black spruce: isolation and identification of allelopathic compounds. Journal of Chemical Ecology, 20: 407-421. doi: 10.1007/BF02064447. 


\section{Figure Caption}

Fig. 1. Stem density of normal, released, stunted (stressed) and total black spruce seedlings recorded in Spracklin road (SR) and Charlottetown (CT) study sites. 
Table 1. Fire history, pre- and post-fire vegetation and soil characteristics of the study sites in Spracklin Road and Charlottetown, Newfoundland.

\begin{tabular}{|c|c|c|}
\hline & \multicolumn{2}{|l|}{ Site } \\
\hline & Spracklin Road & Charlottetown \\
\hline Time since fire (yrs) & 18 & 31 \\
\hline Fire severity index & 466 & 412 \\
\hline \multicolumn{3}{|c|}{ P. mariana stem density (stems ha ${ }^{-1}$ ) } \\
\hline Pre-fire & 5100 & 3240 \\
\hline Post-fire & 188 & 273 \\
\hline Kalmia cover $(\%)^{*}$ & $30 \pm 18^{a}$ & $44 \pm 17^{b}$ \\
\hline Organic matter depth $(\mathrm{cm})^{*}$ & $5 \pm 3^{a}$ & $15 \pm 7^{b}$ \\
\hline Soil pH $\left(\mathrm{H}_{2} \mathrm{O}\right)^{*}$ & $2.9 \pm 0.4$ & $2.9 \pm 0.3$ \\
\hline Soil moisture (\% vol)* & $13.1 \pm 5.5^{\mathrm{a}}$ & $27.9 \pm 6.7^{b}$ \\
\hline Soil temperature $\left({ }^{\circ} \mathrm{C}\right)^{*}$ & $21.7 \pm 1.1^{\mathrm{a}}$ & $18.8 \pm 1.7^{b}$ \\
\hline
\end{tabular}

*Values are mean \pm 1 S.D of measurements taken at the base of sampled seedlings during the month of July. Soil $\mathrm{pH}$, moisture and temperature measured at a depth of $7 \mathrm{~cm}$. Sample sizes for soil parameters were $n=55(\mathrm{SR})$ and $n=43(\mathrm{CT})$ 
Table 2. Growth measurements, ECM colonization and microsite variables around normal, released and stunted black spruce seedlings in Spracklin Road and Charlottetown study sites. Values are reported as mean \pm 1 S.D.

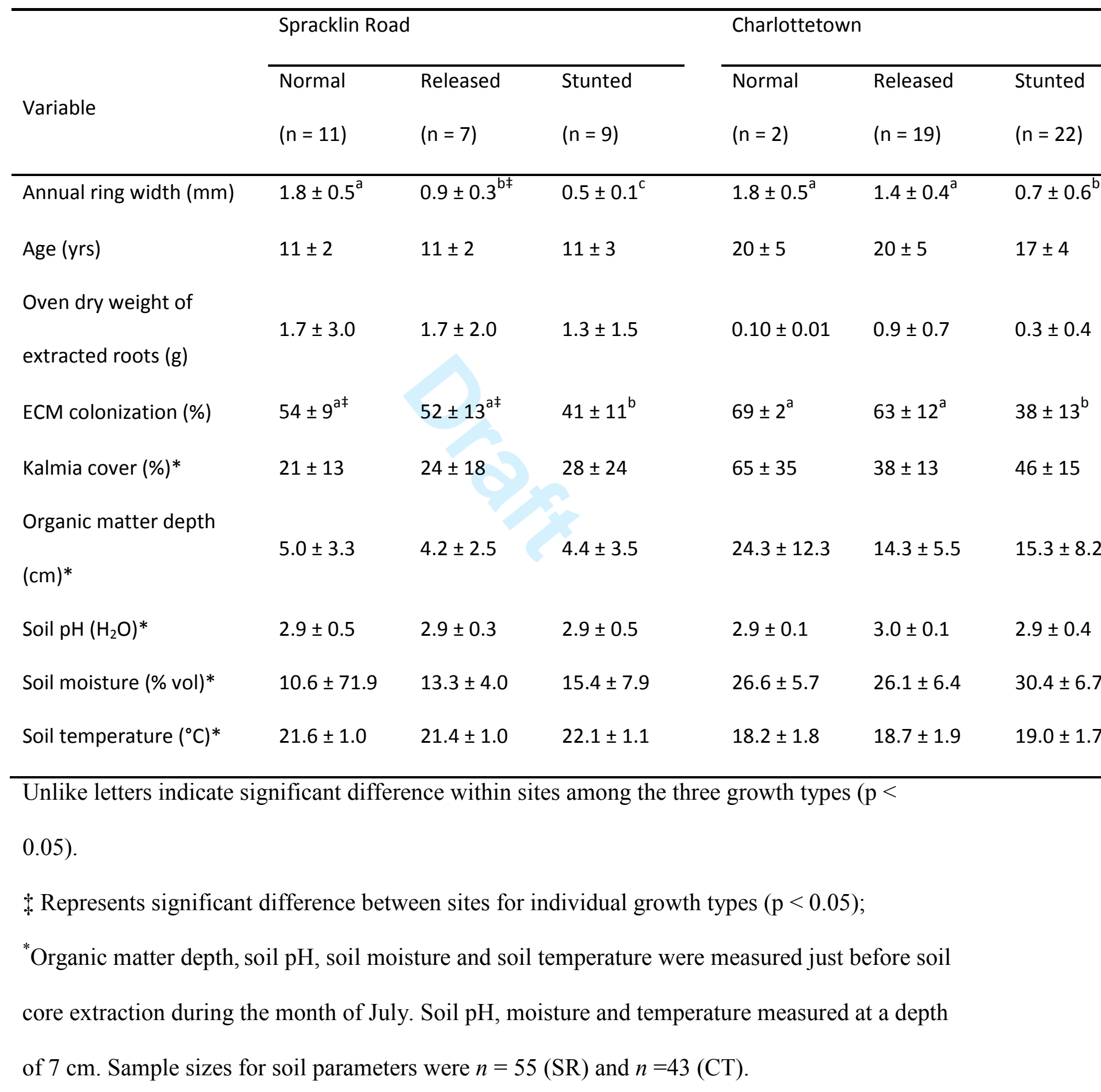


Table 3. Variables among neighbours used to examine spatial patterns in black spruce growth types. Growth type pairs are pooled between the two sites $(n=33)$. Values are reported as mean \pm 1 S.D.

\begin{tabular}{lllll}
\hline & Normal - & Released - & Released - & Stunted - \\
Variable & Released & Released & Stunted & Stunted \\
\hline ECM colonization (\%) & $57 \pm 18^{\mathrm{a}}$ & $52 \pm 11^{\mathrm{ab}}$ & $48 \pm 8^{\mathrm{ab}}$ & $40 \pm 6^{\mathrm{b}}$ \\
Distance between neighbours $(\mathrm{m})$ & $2.3 \pm 0.9$ & $3.8 \pm 1.1$ & $3.6 \pm 1.6$ & $3.3 \pm 1.4$ \\
Years between release events & - & $1.67 \pm 1.73^{\mathrm{a}}$ & $3.50 \pm 1.91^{\mathrm{b}}$ & - \\
Organic matter depth $(\mathrm{cm})$ & $9 \pm 5$ & $7 \pm 5$ & $7 \pm 4$ & $4 \pm 3$ \\
\hline
\end{tabular}

Unlike letter(s) in each line denote a significant difference among growth type pairs $(\mathrm{p}<0.05)$. 
Table 4. Percentage of ECM root tips to total root tips counted (ECM + uncolonized) in normal, released and stunted black spruce seedlings.

\begin{tabular}{|c|c|c|c|c|c|c|}
\hline \multirow[b]{2}{*}{ ECM genera } & \multicolumn{3}{|c|}{ Spracklin Road } & \multicolumn{3}{|c|}{ Charlottetown } \\
\hline & Normal & Released & Stunted & Normal & Released & Stunted \\
\hline \multirow[t]{2}{*}{ Cortinarius } & $35.8 \pm$ & $20.0 \pm$ & $17.3 \pm$ & $0.7 \pm 1.0$ & $21.2 \pm$ & $8.4 \pm 8.5$ \\
\hline & $13.2^{\mathrm{a} \ddagger}$ & $20.6^{\mathrm{ab}}$ & $16.3^{\mathrm{b}}$ & & 24.5 & \\
\hline \multirow[t]{2}{*}{ Piloderma } & $4.6 \pm 6.7$ & $12.7 \pm$ & $9.2 \pm$ & $8.6 \pm 4.1$ & $4.8 \pm 7.0$ & $8.5 \pm 12.6$ \\
\hline & & 15.2 & 14.3 & & & \\
\hline \multirow[t]{2}{*}{ Tylospora } & $4.3 \pm 6.2$ & $4.6 \pm 5.9^{\ddagger}$ & $2.1 \pm$ & $28.1 \pm 36.1$ & $21.0 \pm$ & $9.1 \pm 8.4$ \\
\hline & & & 4.5 & & 16.9 & \\
\hline \multirow[t]{2}{*}{ Tomentellopsis } & $9.5 \pm 8.9$ & $9.8 \pm$ & $8.4 \pm$ & $23.3 \pm 32.2$ & $14.6 \pm$ & $9.0 \pm 9.5$ \\
\hline & & 11.0 & 10.9 & & 15.7 & \\
\hline \multirow[t]{2}{*}{ Leccinium } & 0 & $4.5 \pm$ & $3.8 \pm$ & $8.5 \pm 12.0$ & $0.8 \pm 1.0$ & $2.3 \pm 6.1$ \\
\hline & & 17.3 & 13.3 & & & \\
\hline Lactarius & 0 & $1.5 \pm 5.9$ & 0 & 0 & $0.3 \pm 1.0$ & $0.8 \pm 2.0$ \\
\hline \multirow[t]{2}{*}{ Uncolonized } & $45.8 \pm$ & $47.0 \pm$ & $59.2 \pm$ & $30.8 \pm 2.2^{\mathrm{a}}$ & $37.3 \pm$ & $62.4 \pm 12.9^{b}$ \\
\hline & $9.3^{\mathrm{af}}$ & $13.2^{\mathrm{a} \ddagger}$ & $11.4^{b}$ & & $11.8^{\mathrm{a}}$ & \\
\hline
\end{tabular}




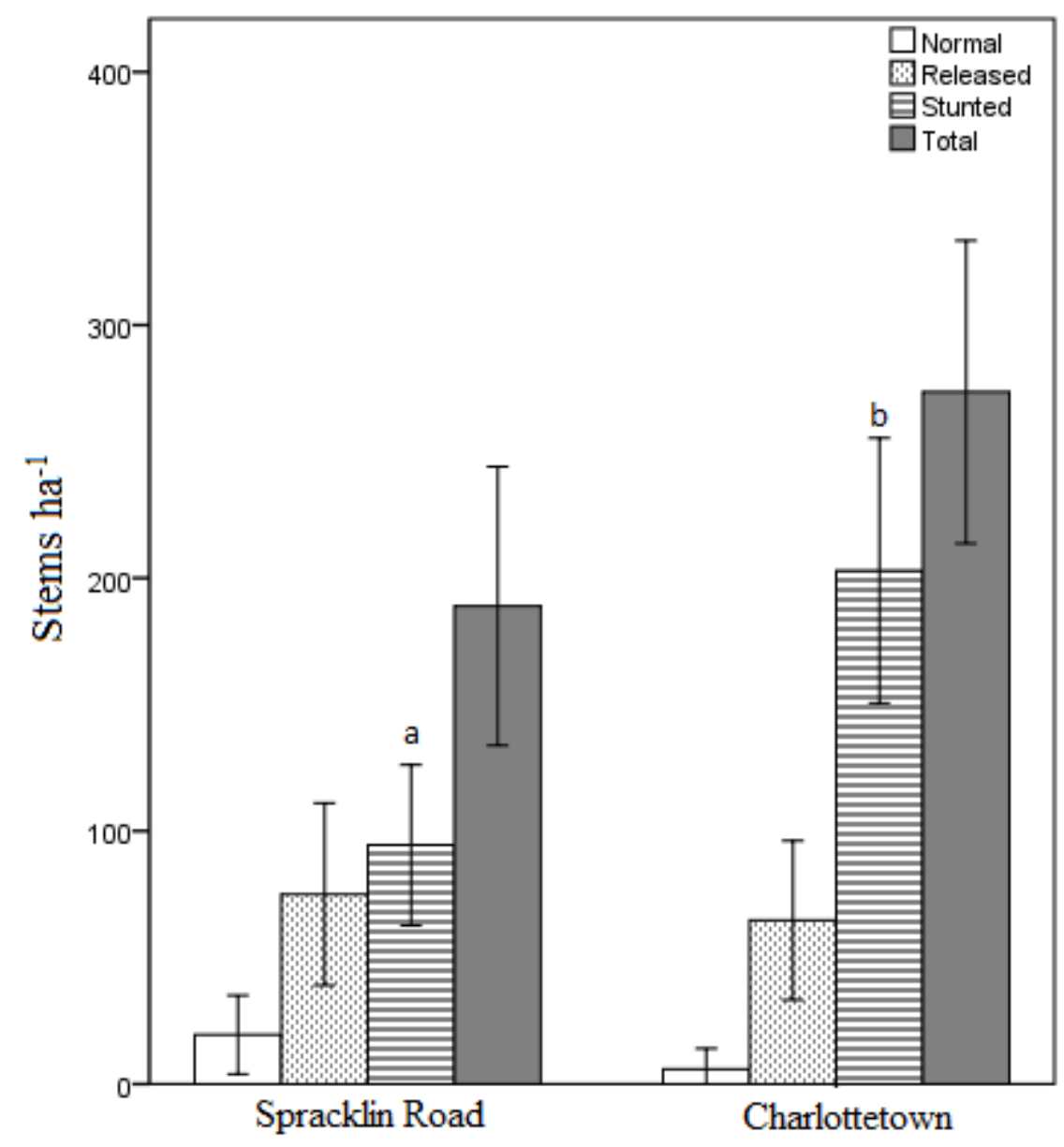

Fig. 1 


\section{Appendix I}

Identification of ECM morphotypes via DNA sequencing and NCBI/UNITE database matches.

\begin{tabular}{|c|c|c|c|c|c|}
\hline Morphotype & Species & $\begin{array}{l}\text { Sequence } \\
\text { length }\end{array}$ & $\begin{array}{l}\text { GenBank } \\
\text { accession \# }\end{array}$ & $\begin{array}{l}\text { Identity } \\
(\%)\end{array}$ & E-value \\
\hline \multirow[t]{2}{*}{ A } & Cortinarius laetus & 383 & FJ157034 & 98 & 0 \\
\hline & Cortinarius sp. 1 & 375 & $\begin{array}{l}\text { HM044581, } \\
\text { JN544449, } \\
\text { FR852018 }\end{array}$ & 99 & 0 \\
\hline \multirow[t]{4}{*}{ B } & Cortinarius brunneotinctus & 417 & HQ604691 & 99 & 0 \\
\hline & Cortinarius cinnamomeus & 386 & FJ157025 & 99 & 0 \\
\hline & Cortinarius sp. 1 & 329 & $\begin{array}{l}\text { HM044581, } \\
\text { JN544449, } \\
\text { FR852018 }\end{array}$ & 99 & $\begin{array}{l}2.00 \mathrm{E}- \\
164\end{array}$ \\
\hline & Cortinarius sp. 2 & 380 & DQ481782 & 97 & $\begin{array}{l}6.00 \mathrm{E}- \\
180\end{array}$ \\
\hline $\mathrm{C}$ & Piloderma sphaerosporum & 432 & JQ711875 & 99 & 0 \\
\hline $\mathrm{D}$ & Tylospora fibrillosa & 325 & JQ712008 & 99 & $\begin{array}{l}3.00 \mathrm{E}- \\
163\end{array}$ \\
\hline $\mathrm{F}$ & Tomentellopsis submollis & 451 & $\begin{array}{l}\text { AY641459, } \\
\text { AM086447, } \\
\text { AJ893354 }\end{array}$ & 99 & 0 \\
\hline G & Leccinum sp. & 431 & $\begin{array}{l}\text { HQ433154, } \\
\text { KC552011 }\end{array}$ & 97 & 0 \\
\hline $\mathrm{H}$ & Suillus cavipes & 455 & JF899572 & 98 & 0 \\
\hline I & Lactarius sp.1 & 333 & AF506411 & 99 & $\begin{array}{l}3.00 \mathrm{E}- \\
163\end{array}$ \\
\hline \multirow[t]{2}{*}{$\mathrm{J}$} & Lactarius sp.1 & 379 & AF506411 & 99 & 0 \\
\hline & Lactarius sp.2 & 405 & DQ481782 & 97 & 0 \\
\hline
\end{tabular}

